\title{
FROM ICE TO ICE-FREE: GLACIATION IN THE LAKE AYR VALLEY, CENTRAL TASMANIA
}

\author{
by R.J.S. Wilson and D.G. Hannan
}

(with five text-figures)

Wil.son, R.J.S. \& Hannan, D.G., 1955 (30:vi): From ice to ice-free: Glaciation in the Lake Ayr Valley, central Tasmania. Pap. Proc. R. Soc. Tasm., 129: 35-42. https://doi.org/10.26749/rstpp.129.35 ISSN 0800-4703. IASOS, University of Tasmania, GPO Box 252C, Hobart, Tasmania, Australia 7001 (RJSW); Department of Physical Sciences, University of Tasmania, PO Box 1214, Launceston, Tasmania, Australia 7250 (DGH).

During the Last Glaciation in Tasmania a large ice cap developed on the western edge of the Central Plateau and overlapped on to the Cradle Mountain-Lake St Clair area. Several reticulate lobes flowed from this source, with the largest northern outlet, the Mersey Glacier, covering an area of c. $282 \mathrm{~km}^{2}$

The Lake Ayr Valley was occupied by a small diffluent lobe of the Mersey Glacier, and the lack of activity caused few erosional features to be formed. Moraines are abundant and can be related to the general retreat phase of the glacial system.

Evidence suggests that retreat was fairly rapid and no re-advance occurred during this period. Deglacial warming was well underway by $11040 \pm 280$ yrs BP (SUA 3060).

Key Words: moraines, Last Glaciation, Lake Ayr Valley, Tasmania.

\section{INTRODUCTION}

The Lake Ayr Valley is situated west of the Tasmanian Central Plateau (fig. 1). It is a characteristic U-shaped glacial valley with altitudes of $850 \mathrm{~m}$ on the valley floor and over $1250 \mathrm{~m}$ on the edge of the Mount Oakleigh Plateau. The valley is located amongst some of the highest mountains in Tasmania, namely Mount Ossa (1617 m), Mount Pelion West $(1554 \mathrm{~m})$, Mount Pelion East $(1400 \mathrm{~m})$ and Mount Oakleigh $(1280 \mathrm{~m})$. Lake Ayr dominates the valley and drains to the west across Pelion Plains, discharging into the Forth River via Douglas Creek. Reedy Lake is a small lake at the eastern end of the valley, over the drainage divide from Lake Ayr, and drains eastwards into the Mersey Valley via Wurragara Creek (fig. 2).

The western part of the study area is underlain by Precambrian quartzite, mica schist and quartz mica schist, which form the basement rocks cropping out widely in the upper Forth Valley (Macleod et al. 1961). These rocks are overlain by post-Carboniferous, horizontally bedded sedimentary rocks, predominantly sandstone and mudstone, belonging to the Parmeener Supergroup (Burrett \& Martin 1989, Macleod et al. 1961). This sequence has been extensively faulted and intruded by transgressive sheets of Jurassic dolerite that now cap the mountains in the area. Outcrop of the Parmeener Supergroup sediments is largely hidden by a cover of Quaternary till, fluvioglacials and solifluction sediments.

This paper presents the results of detailed mapping of glacial features in the Lake Ayr region and provides insight into the style and speed of glacial retreat at the end of the Last Glaciation.

\section{PREVIOUS RESEARCH}

There is a long history of observations of glacial action on the Central Plateau and the surrounding areas. Johnston (1893) was the first to suggest that the Central Plateau could contain an ice cap of sufficient volume capable of supplying "its western alpine valleys with numerous ice streams or glaciers". Reid (1919) surmised that ice from the Central Plateau would have spilled into the Mersey and Forth Valleys. Montgomery (1893) observed roches moutonnées west of Pelion Plains near the present footbridge over Douglas Creek.

Spry (1958) argued that the Mersey-Forth area was subject to both an ice cap and subsequent valley glaciation, and proposed that, during the ice-cap stage, the Forth Glacier reached at least to the present junction of Lemonthyme Creek and possibly as far as Lorinna (fig. 1). Jennings (1959) and Macleod et al. (1961), in detailed geological mapping of the area, recorded abundant glacial deposits in the Pelion Plains area on the interfluve between the Forth and Mersey Valleys.

Derbyshire et al. (1965) rationalised the glacial history of Tasmania and produced the first comprehensive glacial map of Tasmania. They identified moraines in the Lake Ayr Valley and proposed an ice limit at the western end of the valley. Paterson (1965, 1966) and Derbyshire \& Peterson (1971) emphasised the importance of sediments in the reconstruction of the glacial history of the Central Plateau region and obtained the first certain evidence for multiple glaciation in the Mersey and Forth Valleys during the HEC construction work for the Mersey-Forth Power Scheme, when extensive drilling and site works exposed considerable glacial sediment.

Several authors have since established three glacial events in the Mersey Valley (Kiernan 1983, Hannan \& Colhoun 1987, Hannan 1989). Kiernan \& Hannan (1991) have provided reconnaissance data for the Lake Ayr region and established four episodes of glaciation in the Forth Valley. 


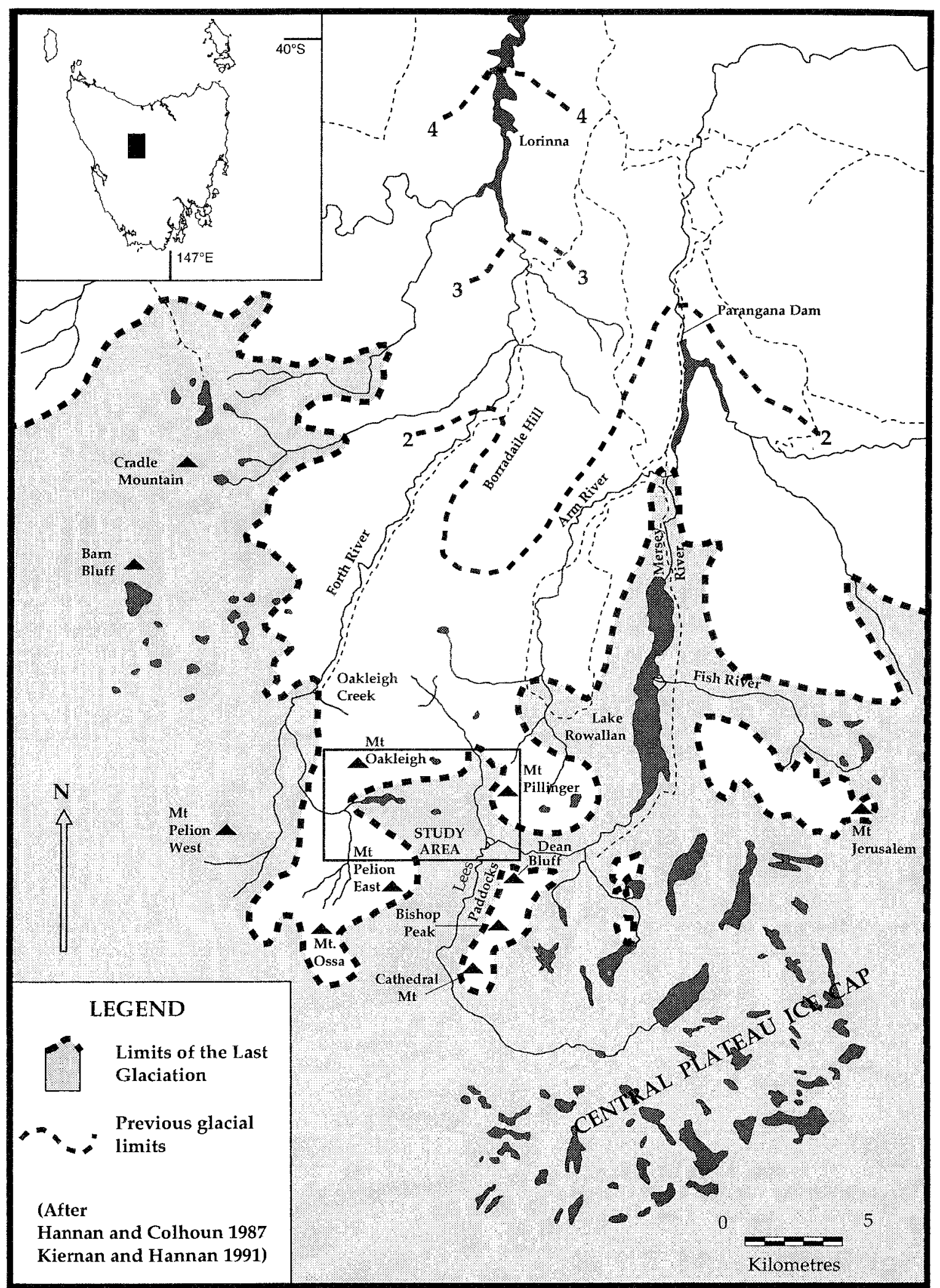




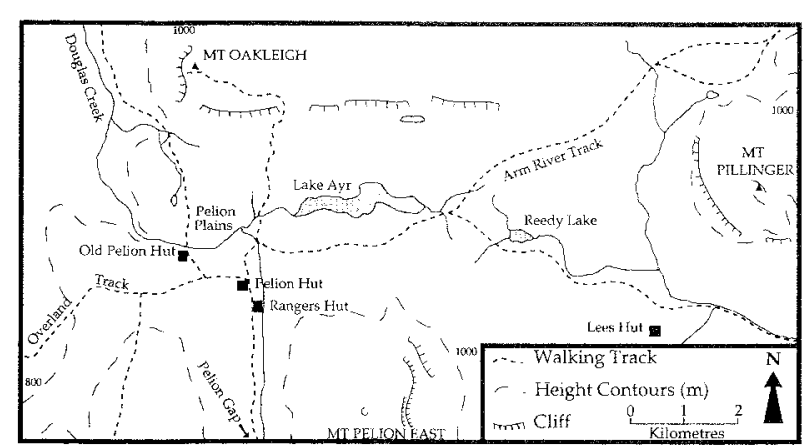

FIG. 2 - The Lake Ayr Valley.

\section{THE LAST GLACIATION IN THE LAKE AYR VALLEY}

\section{Glacial Extent}

During the Last Glaciation, the ice cap on the Central Plateau was the main source for the Mersey Glacier. Ice occupied about $282 \mathrm{~km}^{2}$ of the Mersey Valley and filled the valley in the vicinity of Lees Paddocks to $1000 \mathrm{~m}$, giving an ice thickness of greater than $400 \mathrm{~m}$ (fig. 1) (Hannan 1989). Evidence for this can be found in the creek between Bishop Peak and Dean Bluff, where till outcrops occur at $900 \mathrm{~m}$, with the scree limit on the side of Dean Bluff between $1000 \mathrm{~m}$ and $1100 \mathrm{~m}$ (Hannan 1989) (fig. 1).

Across the valley, on the eastern flank of Mt Pelion East, an arcuate lateral moraine is visible at $1000 \mathrm{~m}$ altitude. This moraine can be traced northwards intermittently and eventually loops around as a latero-terminal moraine west of Lake Ayr. On this evidence, it can be deduced that the surface of the Mersey Glacier was at c. $1000 \mathrm{~m}$, giving an ice thickness in the Lees Paddocks area of about $400 \mathrm{~m}$. At the eastern end of the Lake Ayr Valley, ice would only have been about $160 \mathrm{~m}$ thick. Given that the westward gradient of the valley is small and that this ice did not penetrate through in to the Forth glacial system but ended in a diffluent lobe, it is not surprising that erosional features are not in evidence from what would have been relatively inactive ice. This condition would have been ideal for the deposition of the large number of moraines found in the Lake Ayr Valley.

\section{Glacial Depositional Features}

Terminal, lateral and recessional moraines are observable in the area. These vary in height from a few metres to over $20 \mathrm{~m}$ (fig. 3), the largest being the latero-terminal moraines on the northern and southern sides of the valley. The increase in size of these moraines to the west suggests that the glacial system was at its maximum extent for a considerable period of time. In contrast, the large number of smaller recessional moraines suggest that there was rapid retreat once deglaciation commenced. The central portion of the terminal moraine is not present at the western end and, presumably, has been removed by meltwater erosion as the glacier retreated.

From the middle of the valley towards Mount Pelion East to the south, there are numerous prominent, arcuate moraine ridges, which appear to be arranged in steps. These are found to be replicated northwards towards the Oakleigh Plateau but, because of a steeper slope, are less obvious. On the southern side of the valley, they have the appearance of terraces on the edge of Mount Pelion East, and south of Reedy Lake detailed mapping revealed six levels, but more could be obscured in the dense vegetation.

The moraines in the valley are similar to other moraines in the Mersey Glacial system, in that they are smaller than others of similar age found elsewhere in the state (Hannan 1989). The West Coast Range moraines vary from 100$300 \mathrm{~m}$, those in the Arthur Range are c. $100 \mathrm{~m}$ and in the Snowy Range c. $60 \mathrm{~m}$ in height (Colhoun 1985). This size difference occurs because the Lake Ayr glacial lobe was much less dynamic than the outlet glaciers from these other areas, with a corresponding reduction in erosion and, hence, transportation and deposition. The lack of dynamism has already been mentioned above but can be largely attributed to the fact that the lobe did not penetrate into the Forth System, due to lack of ice thickness above the valley step that separates the Mersey Valley from the Reedy Lake area. As a consequence, erosion was minimal in the flat-floored Lake Ayr Valley.

\section{Glacial Erosional Features}

It is likely that the Last Glaciarion in this region did not radically change the landscape, and glaciers of this age probably followed pre-existing glaciated valleys. Very few erosional features associated with the Last Glaciation can be detected in the Lake Ayr Valley, because of the density of vegetation and extensive Quaternary sediment cover.

Meltwater channels are the most common glaciofluvial erosional feature of the area and can usually be observed alongside moraines, where deflection of pre-existing channels has occurred (e.g. Stockyard Creek - fig. 3). The outlet creek from Lake Ayr was formed in the retreat phase of the Last Glaciation and was originally fed by a proglacial lake. Extensive volumes of meltwater would have caused down-cutting by this creek through the moraines at the western end of the lake. Douglas Creek discharge would have been considerably higher in glacial times and, as a result, it cuts deeply into the quartzite bedrock west of Pelion Plains before draining into the Forth Valley. Figure 4 shows a schematic profile along the central axis of the Lake Ayr Valley, and west of Lake Ayr the valley floor rises before descending into the Forth Valley. This rise is due to the resistant quartzite/schist bedrock, as well as a mantling of morainic material, and indicates the extensive downcutting achieved by Douglas Creek. This deep erosion into the bedrock is undoubtedly partly relict from older glaciations. Last Glacial age meltwater passed through this channel and, at the very least, incised through the morainic material upstream.

Dolerite erratics and quartzite roches moutonnées can be found west of Pelion Plains. These features are likely to be associated with the Penultimate Glaciation, as striations are not visible on the surfaces of the roches moutonnées. Presumably they have been removed by weathering. Weathering rinds on dolerite boulders in the surrounding ground moraine exceed $5 \mathrm{~mm}$ in average thickness, which suggests a Penultimate Glacial age.

The high mountains surrounding the area (Mount Pelion East, Mount Oakleigh, Mount Pillinger and Mount Ossa) were nunataks during the Last Glacial maximum. All were subjected to periglacial conditions for a significant period of time, and distinct evidence of this remains in the form of steep, mantling scree slopes. 


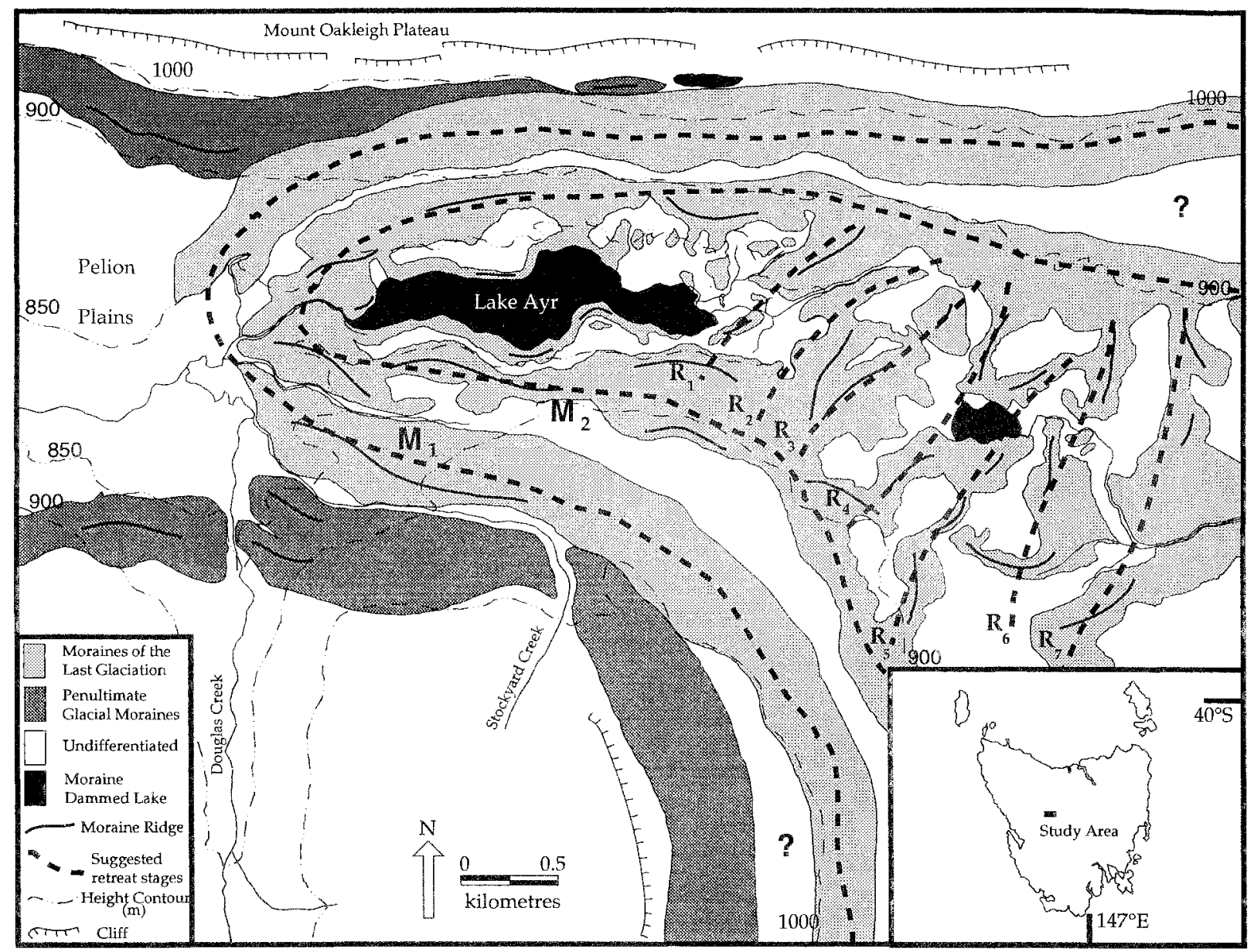

FIG. 3 - Latero-terminal moraines $(M)$ and recessional moraines $(R)$ in the Lake Ayr Valley. Suggested glacial retreat is indicated.

\section{THE LAKE AYR VALLEY DURING THE LAST GLACIAL MAXIMUM}

The maximum extent of Last Glaciation ice in the Lake Ayr Valley has ramifications in the ice budget of the Mersey Glacier. The main point to clarify is whether the ice flowed through the Lake Ayr Valley to join the Forth system. Field mapping has revealed five lines of evidence to show that ice from the Mersey Glacier did not reach the Forth Glacier at this time. These lines of evidence are as follows.

(1) Figure 3 shows the relationship of terminal, lateroterminal, lateral and recessional moraines in the Lake Ayr Valley. The latero-terminal moraine system clearly indicates the maximum extent of the Lake Ayr lobe during the Last Glaciation. An outwash plain commences immediately west of the terminal moraine and forms a part of Pelion Plains which is criss-crossed with relict meltwater channels. Sediment cores taken from the plains west of Lake Ayr, show a continuous peat cover of over $2 \mathrm{~m}$ on top of rhythmites (e.g. Core 6 - fig. 5) which would seem to suggest a proglacial zone.

(2) Lateral moraines of the Penultimate Glaciation are found on the valley edges above the highest latero-terminal moraines of the Last Glaciation. The penultimate moraines have relatively well-developed soil profiles, are incised more deeply by streams and have more rounded crests than the last glacial moraines. The clasts in the older moraines have weathering rinds from $1-6 \mathrm{~mm}$ with an average of $4.7 \mathrm{~mm}$,

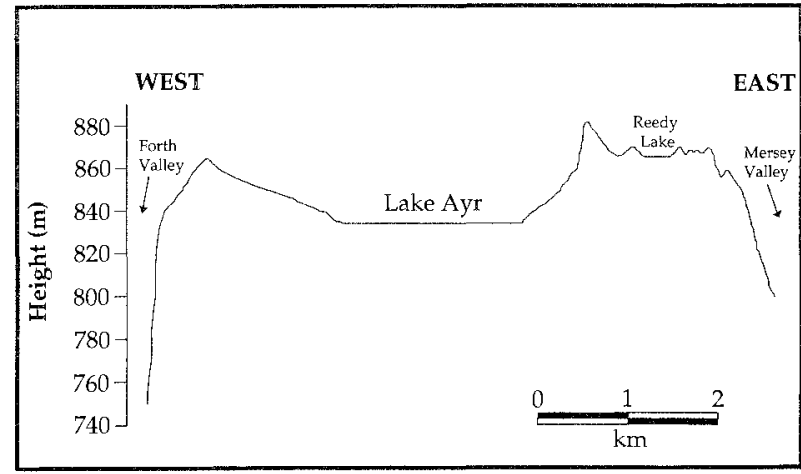

FIG. 4 - Schematic profile of the Lake Ayr Valley. Vertical scale is exaggerated 25 times.

whereas the last glacial moraines have dolerite weathering rinds averaging about $1 \mathrm{~mm}$. The topographic location of Penultimate glacial moraines indicate that they were not overidden by last glacial ice.

(3) The soil profiles within the last glacial terminal moraine zone at the western end of Lake Ayr are not as well developed as the soil around the moraines of the Penultimate Glaciation. The soil visible around Lake Ayr is quite gravelly, lacking in organic horizons and is seldom weathered. Soils on the lateral moraines, high on the sides of the valley, are humified, weathered and have much deeper profiles than the soils on the valley floor. 


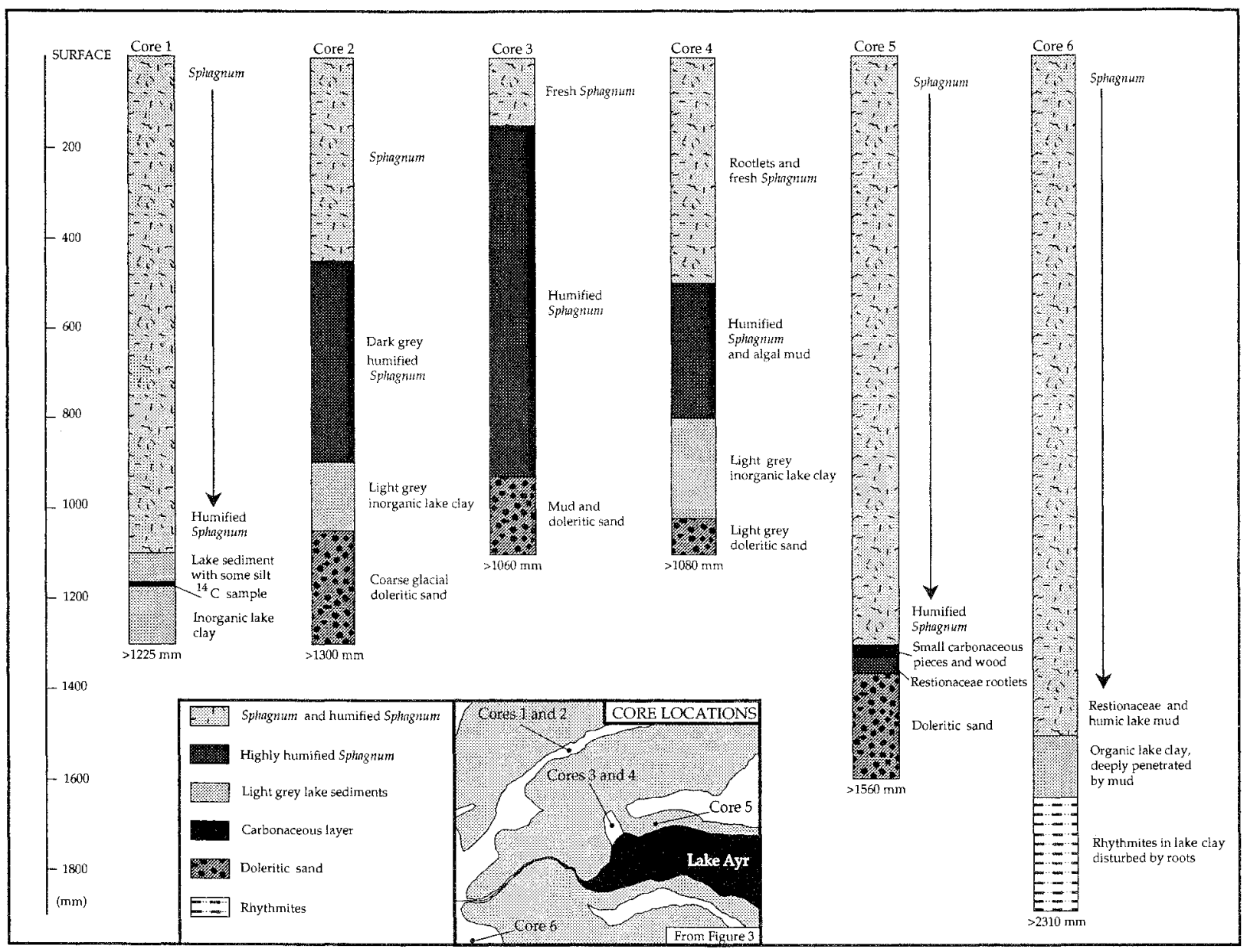

FIG. 5 - Sediment core stratigraphy and locations.

(4) Southwest of the summit of Mount Oakleigh (fig. 2), a small creek is crossed by the Forth Valley track (Grid Reference: 55GDP 198699). Along the creek there are extensive quartzite scree slopes on both sides of the valley. Their presence suggests that last glacial ice did not reach this point, as it would undoubtedly have removed the scree. The position of the creek is sufficiently low in altitude to have filled with last glacial ice had it flowed towards the Forth Valley. There is insufficient time for these thick screes to develop since the Last Glaciation because of the resistant nature of quartzite. They must have formed after the Penultimate Glacial maximum and beyond the maximum limits of last glacial ice. Similar dolerite screes can be found on the sides of the Mount Oakleigh Plateau and Mount Pelion East, above the main latero-terminal moraine of the last glacial lobe in the Lake Ayr Valley. Similarly, these are likely to have developed beyond the maximum limits of last glacial ice and temporally after the maximum of the Penultimate Glaciation.

(5) Further evidence which suggests that Last Glacial age ice did not flow into the Forth Valley via the Lake Ayr Valley is the difference in extent of the Forth and Mersey Glaciers during the Last and Penultimate Glaciations. During the Penultimate Glaciation, the maximum extent of the glacial ice in the Forth Valley is close to Borradaile Hill (fig. 1). During the Last Glaciation, the ice extent was $15 \mathrm{~km}$ upstream, close to Oakleigh Creek. In the Mersey Valley, during the Penultimate Glaciation, the maximum extended just below Parangana Dam (fig. 1), whilst in the Last Glaciation the maximum was $8 \mathrm{~km}$ upstream, close to the confluence of the Arm and Mersey Rivers. This indicates a Penultimate Glaciation of relative greater extent in the Forth Valley compared with the Mersey Valley.

The Forth Glacial System does not have a large catch ment area (Kiernan \& Hannan 1991). A likely reason for a more extensive maximum in the Forth Valley during the Penultimate Glaciation is ice loss from the Mersey System via the Lake Ayr Valley into the Forth system. In the Last Glaciation, ice terminated in the Lake Ayr Valley, and the Forth Valley Glacial System was undernourished and terminated some $15 \mathrm{~km}$ downstream, near the junction with Oakleigh Creek (fig. 1).

\section{DEGLACIATION OF THE LAKE AYR VALLEY}

Moraines are the most common glacial landform in the Lake Ayr Valley, and their shape, position and height allow speculation about the nature of the glacial retreat. Figure 3 shows suggested retreat stages in the Lake Ayr Valley. The main latero-terminal moraine (M1) is the highest moraine in the valley and suggests that the Lake Ayr glacial lobe maintained its maximum position for a reasonable period of time. The latero-terminal moraine $\left(\mathrm{M}_{2}\right)$ is the next highest 
depo sit and similarly indicares that the ice was located at this posit ion for a considerable time. The moraine is, however, not as wide or high as $M$, and was deposited by a much reduced glacial lobe.

A radiocarbon date was obtained from a core taken from a moiaine-dammed bog occurring between moraines $M$. and $M_{2}$ (Core 1 - fig. 5). The sample dated came from a depth of $1.1 \mathrm{~m}$ at an altitude of $860 \mathrm{~m}$ and consisted of a Sphagnum peat layer interbedded berween inorganic lake clay. It gave an age of $11040 \pm 280$ yrs BP (SUA 3060). The presence of Sphagnum in the intermorainal bog suggests a warmer period besween colder conditions. Similar dates have been obtained in other locations in the area for the initiation of warmer conditions. Ac Dublin Bog Lobe in the Mersey Valley, at an altitude $590 \mathrm{~m}$, the post-glacial temperature rise was underway by $13400 \pm 600$ yrs BP (SUA 2188) (Hannan \& Colhoun 1987, Colhoun et al. 1989). A small lobe in Wild Dog Creek near the Walls of Jerusalem, at an altitude of $1180 \mathrm{~m}$, gave an age of 12420 \pm 150 yrs BP (SUA 3046) from algal mud. Given the occurrence of older dates in the region, the date of 11040 \pm 280 yrs BP may not define the time of ice retreat but it gives a minimum age for ice retreat from the Lake Ayr Valley.

The recessional moraines $\left(R_{1}-R_{7}\right)$ are relatively close to each other and only a metre or two high. The regular nature of these moraines and their size suggests a fairly rapid and constant retreat. The low gradient of the valley and the limited ice thickness would have contributed to a rapid retreat, as a small decrease in ice volume in the main Mersey Glacier would have given a relatively larger reduction in the Lake Ayr ice volume. It is assumed that the moraine sequence from $M_{1}$ to $R_{7}$ becomes progressively younger, as there is no evidence to suggest any re-advance of the lobe.

Meltwater would have been considerable at the commencement of deglaciation and was responsible for the deep erosion into moraine $\mathrm{M}_{2}$ and some of the incision of Douglas Creek into the quartzite/schist bedrock near Old Pelion Hut. In the later stages of deglaciation meltwater would have flowed towards the glacier and been responsible for the confused pattern of the moraines $R_{6}$ and $R_{7}$.

\section{CONCLUSION}

In the Mersey-Forth area, there is no clear local evidence which defines the onset of glaciation. In other parts of the state, this has been estimated at c. 25000 yrs BP (Colhoun \& van de Geer 1986). During the Last Glacial Maximum (c. 18000 years ago) the Lake Ayr Valley was glaciated by a diffluent lobe of the Mersey Glacier. The Mersey glacial system, however, was not extensive enough for ice to penetrate through the Lake Ayr Valley to join the Forth Valley glacial system, as had occurred in earlier glacial episodes. Field work in the Lake Ayr Valley has revealed several lines of evidence to suggest that glacial ice during the Last Glaciation did not reach the Forth Valley. The most compelling evidence is the positioning of the moraines and the outwash plain, which were deposited by the glacial lobe. The lateral moraines in the Mersey Valley (at c. $1000 \mathrm{~m}$ a.s.l., Hannan 1989) have equi-valent moraines in the Lake Ayr Valley. These occur at the same height at the eastern end of the valley, but slowly decrease in height westwards until they meet the valley floor west of Lake Ayr (fig. 3). The central portion of the terminal moraine deposited at the snout of the glacier during the Last Glacial Maximum is absent, presumably because it was eroded by meltwater from the retreating glacier. The outwash plain forms part of Pelion Plains, and relict meltwater channels can be seen meandering across the plain before joining Douglas Creek.

From this study, the retreat of the glacial lobe in the Lake Ayr Valley has been dated to have been well underway before $11040 \pm 280$ yrs BP (SUA 3060), which conforms with orher parts of Tasmania. The nroraines in the valley provide evidence of a glacial system that was at its maximum extent for a relatively long period of time. When glacial retreat commenced, it occurred at a steady rate. There is, however, no evidence to suggest re-advance at any time. It is considered generally that Tasmania was ice-free by about 10000 yrs BP (Hannan 1989). A radiocarbon date from a cultural deposit in the upper Mersey Valley of $9760 \pm 720$ yrs BP (Beta 4757) indicates that the upper Mersey Valley was deglaciated by this time (Lourandos 1983).

\section{ACKNOWLEDGEMENTS}

The main phase of this study was undertaken as part of an Honours thesis in IASOS at the University of Tasmania by the first author of this paper (Wilson 1994). Special thanks go to Patricia Wells for her invaluable help in the compilation of the second half of the thesis. For logistical support for this study, I am grateful to IASOS and Rod Ledingham of the Antarctic Division. I also wish to thank the Department of Parks, Wildlife and Heritage, Mark Collier, Max Howe, Bill Budd, Andrew Ruddel and Barbara Lewis.

\section{REFERENCES}

Burrett, C.F. \& Martin, E.L., 1989: GEOLOGY AND MINERAL RESOURCES OF TASMANIA. Geol. Soc. Aust. Spec. Publ. 15: 574 pp.

Colhoun, E.A., 1985: Glaciations of the West Coast Range, Tasmania. Quat. Res. 24(1): 39-59.

Colhoun, E.A. \& van de Geer, G., 1986: Holocene to Middle Last Glaciation vegetation history at Tullabardine dam, western Tasmania. Proc. R. Soc. London Ser. B 229: $177-$ 207.

Colmoun, E.A., van 1) Gefr, G. \& Hannan, D.G., 1989: Late Glacial and Holocene History at Dublin Bog, NorthCentral Tasmania. Aust. Geogr. Stud. 29: 337-354.

Derbyshire, E. \& Peterson, J.A., 1971: On the status and correlation of Pleistocene glacial episodes in south-eastern Australia. Search 2: 285-288.

Derbyshire, E., Banks, M.R., Davies, J.L. \& Jennings, J.N., 1965: GLACIAL MAP OF TASMANIA. R. Soc. Tasm. Spec, Publ. 2: 11 pp.

Hannan, D.G., 1989: The Glacial History of the upper Mersey Valley. Unpubl. MSc thesis, Univ. Tasm.

Hannan, D. \& ColHoun, E.A., 1987: Glacial stratigraphy of the Upper Mersey Valley, Tasmania. Aust. Geogr. Stud. 25: 36-46.

Hannan, D.G. \& Colhoun, E.A., 1991: When were the Walls of Jerusalem Last Glaciated. Pap. Proc. R. Soc. Tasm. 125: $1-6$.

Jennings, I.B., 1959: Geology of the Cradle Mountain Reserve. Tech. Rep. Dep. Mines Tasm. 3: 73-78.

Johnston, R.M., 1893: The Glacier Epoch in Australia. Pap. Proc. R. Soc. Tasm: 73-134.

KIERnAN, K., 1983: Weathering evidence for an additional glacial stage in Tasmania. Aust. Geogr. Stud. 21: 197-220.

Kiernan, K. \& Hannan, D., 1991: Glaciation of the Upper 
Forth River Carchment, Tasmania. Aust. Geogr. Stud. 29(1): 155-173

Lourandos, H., 1983: 10,000 years in the Tasmanian Highlands. Aust. Arch. 16:39-47.

Maclfod, W.N., Jack, R.H. \& Threader, V.M., 1961: Du Cane, Tasmania. 1 Mile Geol. Arlas Ser. Explan. Rep.: K55-11-52. Tasm. Dep. Mines.

Mon'comery, A., 1893: Glacial action in Tasmania. Pap. Proc. R. Soc. Tasm. 159-169.

Paterson, S.J., 1965: Pleistocene drift in the Mersey and Forth valleys - Probability of two glacial stages. Pap. Proc. R. Soc. Tasm. 99: 115-124.
Paterson, S.J., 1966: Pleistocene deposits at Parangana damsite in the Mersey Valley. Pap. Proc. R. Soc. Tasm. 100: 147151.

Rem, A.M., 1919: The Mr. Pelion Mineral District, Bull. Geol. Surv. Tasm. 30:14-17.

SPRY, A., 1958: The Precambrian rocks of Tasmania; part III, Merscy-Forth area. Pap. Proc. R. Soc. Tasm. 92: 117 137.

WIIson, R.J.S., 1993: The Last Glaciation in the Lake Ayr Valley, Central Tasmania. Unpubl. Hons thesis, Univ: Tasm.

(accepted 10 October 1994) 